\title{
TEATRALIDAD Y ELEMENTOS FANTÁSTICOS EN LAS CASAS DEL TERROR
}

\author{
Miguel Carrera Garrido \\ Universidad Marie-Curie-Skolowska de Lublin (Polonia) / \\ Instituto del Teatro de Madrid (ITEM) \\ mcarreragarrido@gmail.com
}

Recibido: 30-06-2014

Aceptado: 07-10-2014

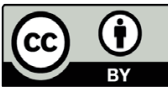

\section{RESUMEN}

En este texto defino las casas del terror como la forma escénica más propicia para la recreación del miedo. Ante las limitaciones del teatro convencional para este fin, se presentan las casas del terror como la opción más fecunda, llevando al límite la ruptura de la cuarta pared y haciendo intervenir al público en el espectáculo. Normalmente desechadas por la academia, en torno a ellas no existe bibliografía científica. Comienza, pues, el artículo por definir el objeto de estudio y ofrecer ejemplos significativos. Procede a continuación a legitimar su naturaleza enteramente teatral, vinculándolo con la línea posdramática; y en última instancia, toma en consideración el papel que juegan los elementos sobrenaturales en la respuesta emocional de los asistentes, lo cual sirve de base para entender el funcionamiento profundo de las casas del terror.

PAlABRAs ClAVE: casas del terror; teatralidad; interactividad; terror; fantástico.

\section{Abstract}

In this text I define haunted attractions as the most suitable stage form to recreate fear. In light of the limitations of conventional theatre in this regard, haunted attractions become the most productive option, pushing the rupture of the fourth wall to the limit and involving the audience in the show. Normally dismissed by the Academy, there is no scientific bibliography about them. The article starts off, then, defining the object of study and offering significant examples. It goes on to demonstrate its fully theatrical nature, linking it with the postdramatic; and lastly, takes into consideration the role played by supernatural elements in the participants' emotional response, 
which contributes to an understanding of the deep functioning of haunted attractions.

KEYwords: haunted attractions; theatricality; interactivity; horror; fantastic.

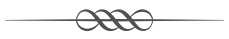

\section{INTRODUCCIÓN}

En mi artículo, que surge de un texto anterior, en el que me planteaba las aptitudes de la escena para recrear el miedo tal y como lo hacen la narrativa y el cine, me propongo estudiar las casas del terror como sucedáneos teatrales, donde lo fantástico y terrorífico encontrarían un acomodo equiparable al que disfrutan en el cuento breve y en el largometraje; equiparable, vale aclarar, en términos de aprovechamiento y explotación de las posibilidades del género, más que en un plano semiológico o pragmático; pues, como traté de demostrar en mi anterior aporte, la mera traslación de las técnicas novelescas o cinematográficas a la escena delata las limitaciones de esta, no por cuestiones materiales, sino por otras de mucho mayor calado, como la intromisión de lo real y la imposibilidad de recrear una subjetividad genuina. ${ }^{1}$

Modalidad hondamente autorreferencial, cuya ontología se basa en el extrañamiento y la aceptación tácita de la improbabilidad, o directa imposibilidad, de los acontecimientos narrados, la ficción terrorífica (especialmente en su variante sobrenatural) se enfrenta en las tablas a un exceso de realidad que va en detrimento de su eficacia como producto ficcional: paradójicamente asentado en unos principios realistas, la disrupción del statu quo representada por la intromisión de lo imposible o monstruoso revela la condición de cartón-piedra de aquel: ya Freud (1919: 34), en su ensayo sobre lo siniestro, notaba esta particularidad, y es un punto recurrente, universalmente asumido, en las consideraciones sobre lo fantástico (cfr. Roas, 2011: 14, De Beni, 2012: 36). En cuanto a la identificación subjetiva -piedra de toque del género²-, es, en sen-

1 El texto aludido saldrá publicado a lo largo del presente año, en las actas del Simposio Internacional «El teatro español como objeto de estudio a comienzos del siglo XXI», que tuvo lugar en la Universidad de Varsovia en los días 27 y 28 del pasado marzo (Carrera Garrido, 2014).

2 «No hay mejor manera de representar el miedo que fomentando la subjetividad» (Sánchez, 2002: 312). También Todorov (1970: 61) vincula la identificación con el discurso fantástico. Aclara, con todo, desde su perspectiva inmanentista, que esta «no debe ser tomada como un juego psicológico individual: es un mecanismo interior al texto, una inscripción estructural». 
tido estricto, irrealizable en la representación dramática, al carecer esta de una mediación que oriente la mirada del espectador y la iguale con la experiencia de los personajes (llámese voz narrativa u ojo de la cámara) (cfr. García Barrientos, 2001: 42). Técnicas como los efectos de inmersión buerianos o expedientes basados en los medios audiovisuales (cfr. Pavis, 2008: 132 y ss.) proponen una solución provisional a esta constricción; aun esta, por desgracia, resulta insatisfactoria, máxime cuando lidiamos con un asunto tan privado e intransferible como es el miedo.

Todo esto no quiere decir que el terror no pueda manifestarse sobre un escenario. Muy al contrario, es precisamente la inmediatez del teatro lo que propicia un efectismo inédito en los demás medios: hablo de la posibilidad de romper la cuarta pared y llevar a la despavorida audiencia a cuestionar los límites entre la ficción y la realidad. En un libro o un filme, los monstruos no se materializan para aterrorizar al receptor: el espanto que se experimenta ante ellos será siempre por delegación, en simbiosis con la vivencia de los sufrientes protagonistas. En el teatro, en cambio, el horror puede llegar a sentirse en la propia piel. «What a clever horror stage production does is to remind the audience that the sense of danger is as real to you as it is to the people on stage», dice el actor y dramaturgo británico Andy Nyman (2014), coautor del exitoso espectáculo Ghost Stories (2010). Por supuesto, prevalece el pacto ficcional y nadie pensará que aquello no es una simulación, un juego, análogos a los narrativos o fílmicos; ${ }^{3}$ la proximidad física ostenta, con todo, un inmenso potencial catártico, impensable en esos otros dominios. Aquel, es cierto, se logra a costa de abandonar los tradicionales mecanismos de la ficción, poniendo en jaque la dicotomía axial sala/escena y haciendo de los espectadores partícipes directos del espectáculo; rupturas que nos asoman a los umbrales de la figuración escénica como se ha entendido desde Aristóteles. Nada de ello impide, con todo, considerar los horizontes que se le abren al terror, en concreto, y a la representación escénica, en general. Al revés: es justo tal vacilación al borde del precipicio lo que más estimula el análisis y el afán por caracterizar formas expresivas no tanto novedosas como desatendidas por la crítica. ${ }^{4}$

La elección de las casas del terror parte de la convicción de que es en ellas, más que en el ámbito de un escenario prototípico, dominado por la mí-

3 «[P]ara responder adecuadamente a algo como una película de terror -para permanecer en nuestros asientos en lugar de llamar al ejército- tenemos que creer que estamos ante un espectáculo de ficción», dice Carroll (1990: 150) en su capítulo sobre la teoría de la ilusión aplicada al terror. 4 Otro coto que podría compararse en estos términos, y que también está siendo reivindicado desde los estudios sobre lo fantástico, son los videojuegos. Sintomáticamente, el próximo número monográfico de Brumal (primavera de 2015) se consagrará a este ámbito. 
mesis tradicional, donde la teatralización del horror se puede llevar hasta sus últimas consecuencias; con todas las irregularidades aludidas, pero no por ello, necesariamente, con menos mérito artístico o imaginativo... aparte, claro está, del recreativo. La argumentación comenzará por escrutar la idiosincrasia de estos espectáculos, con citas a ejemplos tomados de la realidad española; como se verá, existe un amplio margen de sofisticación, que trasciende la consabida atracción de feria. Pasaré luego a fundamentar la naturaleza teatral de la casa del terror, habitualmente limitada a un prisma lúdico y mercantil, para, por último, indagar de qué manera se integran y vehiculan el terror y lo fantástico en tales contextos.

\section{DEFINICIÓN Y EJEMPLIFICACIÓN DEL OBJETO DE ESTUdIO}

Antes de entrar a discutir el objeto de este trabajo, considero fundamental definir a qué me refiero cuando digo casa, túnel o aun pasaje del terror. El Diccionario de la RAE no incluye ninguno de estos términos en sus páginas. No es el único. De hecho, es difícil hallar una definición convincente, ya no digamos de una fuente académica o acreditada. Con todas las cautelas del mundo, nos asomamos a Wikipedia-inmejorable instantánea del conocimiento popular- para toparnos con unas líneas clarificadoras sobre el fenómeno. Es en la versión inglesa donde encontramos la información más detallada (la española no es sino una traducción muy resumida de aquella, acompañada de enlaces a muestras patrias a las que después me referiré). Recogida bajo la denominación genérica Haunted attraction (simulated), ${ }^{5}$ leemos que se trata de «a form of entertainment that simulates the experience of entering a haunted location that might be inhabited by ghosts, monsters, criminals, serial killers, or humorous characters». A continuación se añade que la acción puede desarrollarse en localizaciones tan heterogéneas como «dilapidated homes, abandoned asylums, old prisons, ships, boats, run down grocery stores, semi trucks, factories, shopping malls, fields, farms, and parks»; y más abajo se enumera una nutrida lista de variantes de la atracción (nada menos que catorce), que paso a resumir brevemente, y que habrá de servir de marco para mis apuntes:

1) Haunted house: es la prototípica casa del terror; haciendo uso del motivo del bad place o lugar maldito (cfr. Palacios, 2002: 200), puede ambientarse en cualquier tipo de edificio o espacio popularmente asociado a maldiciones

5 http://en.Wikipedia.org/wiki/Haunted_attraction_\%28simulated\%29 [Consulta: 17/10/14]. 
y presencias del otro mundo (desde una mansión victoriana a un hospital abandonado, pasando por una fábrica, un centro comercial o incluso un barco); este puede haber sido edificado para la ocasión -en forma de caseta de feriante o construcción más sólida- o tratarse de un inmueble reciclado para este propósito. Normalmente son guiadas, aunque no se descarta que los asistentes vayan a su paso. La primera atracción de este tipo de la que se tiene constancia se construyó en 1915; aún en activo en la actualidad, se sitúa en la feria-museo «Hollycombe», ubicada al sur de Inglaterra. ${ }^{6}$ En cuanto a las primeras versiones modernas, ubicadas en localizaciones reales, datan de finales de los 60 y principios de los 70, y nos llevan a ciudades americanas como Cincinnati, Louisville o Lexington. ${ }^{7}$

2) Haunted experience: mezcla el primer tipo con una suerte de búsqueda del tesoro-scavenger hunt-en la que se ven embarcados los participantes y que suele culminar en la casa encantada en sí. Wikipedia apunta el ejemplo de Nyctophobia, realizado por primera vez en Long Island en 2010: en esta experiencia un número de asistentes son recogidos en un punto acordado de antemano y llevados con los ojos vendados al lugar donde va a tener lugar el espectáculo. ${ }^{8}$

3) Haunted trail/forest: como el propio nombre indica, se celebra al aire libre, en una parcela de bosque debidamente acondicionada o en el contexto de un parque de atracciones. El recorrido incluye diferentes localizaciones, como cabañas o claros, en las que se representan escenas de diverso tipo, muchas veces basadas en personajes o episodios fílmicos (Freddy Krueger, Mike Myers, la niña de El exorcista, etc.); tal detalle, por cierto, no es privativo de este subtipo.

4) Haunted hayride: parecida a la anterior, se desarrolla en una granja o, en todo caso, en un entorno agreste, al que se asocian espontáneamente no solo personajes y escenas de libros y películas, sino también figuras del folclor -el Jinete Sin Cabeza, por ejemplo, amén de una anónima pléyade de brujas, demonios y otros seres- y truculentas anécdotas de la historia de la Deep America (a menudo inventadas ad hoc). A diferencia de las modalidades precedentes, propicia una mayor libertad, así como un contacto real con utensilios y emplazamientos del mundo rural (como que los participantes son conducidos a la arena en vehículos propios de este orbe, como tractores y carromatos).

6 www.hollycombe.co.uk/attractions/steam_at_the_fair/haunted_house [Consulta: 17/10/14].

7 http://www.houseofdoom.net/vintage [Consulta: 17/10/14].

8 http://nyctophobiahaunt.com/ [Consulta: 17/10/14]. 
5) Haunted theme park (screampark): se trata de un parque enteramente consagrado a esta forma de espectáculo, en el que confluyen todo tipo de variantes, desde espectáculos cuasicircenses en los que el espectador no interviene de manera activa hasta sobresaltos improvisados, causados por actores que deambulan por las instalaciones de incógnito. Debido a su desmedida naturaleza, su celebración se restringe a fechas señaladas y a espacios de gran envergadura.

6) Dark maze/chain maze: puede formar parte del recorrido de una de las formas ya glosadas o funcionar de modo autónomo. Consiste en un pasaje total o parcialmente a oscuras, en el que el asistente se ve hostigado por golpes de aire, gritos desgarradores, luces parpadeantes, chorros de agua, empujones, etc. La idea es desorientar al máximo al cliente, y que no sea capaz de encontrar la salida. Se contempla una variante con el suelo y las paredes cubiertas de cadenas y metal (de ahí el sustantivo chain).

7) Horror art experience: combina la instalación artística con los recursos típicos de las casas del terror, sin desatender los elementos teatrales. Se introducen en ella reflexiones sobre la política y la sociedad contemporáneas, lo cual da cabida al terror real (político, religioso... no artístico) y la hace no apta para todos los públicos... ni siquiera para los fans del espanto. Un ejemplo sería el espectáculo extremo Blackout, más parecido, según un cronista, a $\mathrm{Abu}$ Ghraib que a Scooby Doo (Hoby, 2011).

8) Hell house: propuesta de inspiración cristiana; tras un via crucis por los tormentos del infierno, se ofrece, como recompensa, una proyección de las virtudes del cielo. Se organiza en torno a viñetas con una simple, pero eficaz, narrativa (a veces inspirada en las Escrituras), con las que se pretende no solo asustar, sino también adoctrinar religiosamente al asistente, al que se increpa por sus pecados. Como se imaginará, estas atracciones han causado no poca polémica. 9

9) Dark ride: probablemente la menos teatral de todas las variantes. Se trata de un paseo en vagoneta por un escenario interior totalmente artificial, en el que se van sucediendo los sustos. Puede realizarse sin actores ni diálogo; su efectividad se basa, más que en ningún otro caso, en los efectos especiales (sonoros, lumínicos y de maquillaje, sobre todo).

9 Una de las más famosas lleva por nombre «Scaremare» y está situada en el estado de Virginia. En la web se lee que la experiencia gira en torno a la pregunta «qué ocurre cuando muero» y que al final, «visitors are presented with an answer to this question and given the life-changing message of Jesus Christ. Approximately 26,000 people have made decisions for Christ over the past two decades. Ironically, this House of Death points to the Way of Life!» (http://www.liberty.edu/scaremare/ [Consulta: 17/10/14]). 
10) Cornfield maze: muy similar a la sexta modalidad, consiste en un laberinto artificialmente diseñado en un campo de maíz -al aire libre, por tanto- que puede limitarse a la simple búsqueda del camino o incluir escenas con actores y despliegue escenográfico (en sentido amplio). Parece existir una verdadera competición entre los creadores de este tipo de atracciones, llegando a alcanzar tamaños monstruosos. Así, en 2003, un laberinto diseñado en la región inglesa de Dorset -el «Lobster Maize Maze»- elevó la marca récord a más de 14000 kilómetros. $^{10}$

11) Home haunt: versión casera de la primera forma, auspiciada por particulares en torno a las fechas de Halloween y cuyos beneficios suelen ir destinados a fines caritativos. Uno diría que la sofisticación de este tipo de casas ha de ser menor que el de las oficiales, mas no tiene por qué ser así: la afición de los estadounidenses a este tipo de espectáculo no tiene parangón, como pude comprobar en persona durante mi estancia en Rhode Island en 2010. Allí tuve la ocasión de contemplar verdaderas maravillas.

12) Yard haunt/yard display: extensión de la anterior modalidad, muchas veces sin hilo narrativo alguno, que se vive antes como obra de arte estática -ponderando el tiempo y el dinero invertidos por una familia o un sujeto en decorar su jardín y adaptarlo a las exigencias de la atracción- que como experiencia teatral. Abundan en ellas los fantasmas, las brujas y los duendes, junto a las consabidas calabazas.

13) Ghost run: reminiscente de la segunda modalidad, entraña la búsqueda de las propias casas del terror, diseminadas a lo largo de una ciudad o un territorio aún más amplio. Al término de la temporada, el conductor que más distancia haya recorrido y más localizaciones haya pisado recibe un premio en metálico. La interferencia con el formato concurso pone en jaque, como en la haunted experience, la teatralidad del conjunto, no así de las casas por separado.

14) Midnight spook/ghost shows: podría decirse que constituyen la prehistoria de las actuales casas del terror; espectáculos que incluían números de magia y efectos perturbadores y que, con frecuencia, servían de complemento a proyecciones cinematográficas. Triunfan en las capas populares de Norteamérica entre 1930 y 1960, desapareciendo con la irrupción de las otras modalidades.

Como se puede apreciar, el fenómeno es mucho más heterogéneo y versátil de lo que, en un principio, se imaginaría. Ello podría llevar a recelar

10 http://news.bbc.co.uk/2/hi/uk_news/england/hampshire/dorset/3054847.stm [Consulta: 17/10/14]). 
del acierto de usar un mismo término para englobar tanta diversidad. Creo, sin embargo, que para evitar la dispersión y servir mejor a los objetivos de este artículo, es conveniente dejarlo así; después de todo, el factor que más me interesa es algo que todas estas formas comparten: la voluntad de atemorizar a un público físicamente implicado en el show. Cabe advertir, eso sí, que muchas de ellas solo tienen presencia, de momento, en el contexto estadounidense, donde, como ya avancé, existe toda una subcultura del túnel del terror. ${ }^{11}$ Popularizados en los años 80, al amparo del boom del género en el cine de este país (cfr. Carroll, 1990: 19-24), hay una relación directa entre estos espectáculos y la festividad de Halloween (lo cual no quiere decir que no pueda tener lugar en otra época del año). En España, donde la Noche de las Brujas no tiene tanta tradición, la casa del terror en sus versiones más elaboradas ostenta una trayectoria mucho menos dilatada que en Estados Unidos o Inglaterra (pese a que una de las principales muestras en suelo británico -el lacónicamente denominado «Pasaje del Terror»- fuera en su origen producto español). ${ }^{12}$ Los últimos años han visto, aun así, una creciente proliferación de propuestas, la mayoría modelada a partir de los referentes anglosajones, pero también algunas con sabor propio, erigidas a partir de motivos locales. Se ha instaurado, por otro lado, la moda de contratarlas para cumpleaños o despedidas de soltero, y es normal incluir servicios como comida o alojamiento. Aunque me gustaría detenerme en todas ellas, los límites de espacio aconsejan restringirse a un par de ejemplos significativos y dejar el resto anotado. Me decanto, pues, por una compañía en concreto -la madrileña «Factoría de Terror»- y un evento: Psicofobia, celebrado en Huétor Vega (Granada).

Fundada en 2004 por la actriz y psicóloga Zoraida Marín, la «Factoría de Terror», apoyada en la productora «La Antigua Factoría», combina pro-

11 Prueba de ello es la existencia de una «Haunted House Association», dedicada, como leemos en su web, «to helping advance, promote and educate the World about the Haunted House and the Halloween industry» (http://www.hauntedhouseassociation.org/haunted_house_directory.cfm [Consulta: 17/10/14]). Esta página, por cierto, es un buen ejemplo del túnel del terror -en todas sus dimensiones, no solo restringido a la casa encantada-concebido más como un negocio rentable, indefectiblemente asociado a una fecha concreta y un público muy específico, que como una posible forma de arte, abierta a todas las virtudes y posibilidades propias de una representación escénica. Para más evidencias de la popularidad de esta atracción en Norteamérica, véanse magacines online como Haunted Attraction, Hauntworld, $13^{\text {th }}$ Hour o Fright Times, todos ellos imbuidos del espíritu comercial de Halloween y donde podemos encontrar jugosas informaciones sobre el funcionamiento, la composición y la fortuna de innumerables pasajes concretos, así como entrevistas a profesionales que trabajan en ellos y detallados catálogos de ferias, encuentros e inauguraciones. El foco está puesto no solo en los consumidores, sino también en los propios artífices, con abundantes referencias a formas de maquillaje, escenografía de toda índole y otros efectos especiales.

12 http://www.pasajedelterror.com/ [Consulta: 17/10/14]. 
puestas que podríamos llamar convencionales con otras del corte que nos interesa (todo ello contratable por colectivos o particulares). En su página $w_{e b}{ }^{13}$ se puede consultar el currículo de la productora, que también incluye espectáculos de magia, recreaciones de duelos, etc. Se impone, de cualquier modo, el interés por el terror y la relación que el público establece con la escena. Significativamente, la trayectoria del grupo va desde la interactividad a la recuperación de la cuarta pared; estimulados por el reto de «generar el miedo del espectador sin que este sea partícipe de la trama», inician una nueva etapa con la pieza Escena cero (2010), asentada en una narración plenamente discernible. No se resisten, pese a todo, a explotar la inmediatez de las tablas: así, «los actores se moverán entre el público y utilizarán todas las instancias del teatro. La cercanía del público con el actor será tanto física como psicológica». Cabe notar, asimismo, el sesgo marcadamente metaficcional de la obra, ambientada en una sala de teatro y protagonizada por actores, así como el margen dejado a la improvisación (no en vano, el subtítulo reza «El terror no está escrito»). Dichos elementos siguen presentes en sus otras creaciones normales: Año de llantos, inspirada en un relato de Teo Rodríguez, y Año de cicatrices, homenaje al Grand Guignol. En ambos dramas, englobados bajo el título general Cerca del miedo (2011), «[e]l espectador no es pasivo, sino que es introducido en la escena como parte del mismo decorado, dejando que sus emociones intervengan en ella». A ellos se une un espectáculo de transición: La valiente (2010); en él la audiencia asiste a la representación de una obra inexistente: pasados dos minutos, comienzan a oírse ruidos extraños y sentirse presencias en la sala; los intérpretes, nerviosos, dejan de actuar e intentan abandonar el teatro; la cosa se pone interesante cuando empiezan a percibirse los llantos de una niña. Como leemos, «el público desde sus butacas será partícipe de todo lo que ocurra... los actores ya no tendrán en cuenta la cuarta pared, ellos también tienen miedo».

Los orígenes de la «Factoría de Terror»se remontan a las formas más arquetípicas. La misma fundadora trabajaba en el mítico «Viejo Caserón», sito en el Parque de Atracciones de Madrid (clausurado este mismo año, por cierto). Esta experiencia es fundamental para entender sus primeras creaciones. De esta etapa hay que destacar la elaboración y versatilidad demostradas, es-

13 http://factoriadeterror.com/terror2.html [Consulta: 17/10/14]. Véase, asimismo, el blog de la compañía: http://elespectaculodelterror.blogspot.com/ [Consulta: 17/10/14]. En los últimos tiempos, sea como fuere, el colectivo tiene más presencia en Facebook (https://www.facebook.com/ factoriadeterror?fref=ts [Consulta: 17/10/14]): ahí se pueden consultar multitud de documentos gráficos. 
pecialmente en el aspecto espaciotemporal: con una duración perfectamente prevista -que oscila entre las dos y las cinco horas- y un número máximo de asistentes, los espectáculos se ofrecen en seis tipos de ubicaciones. Dejando a un lado el aspecto plástico (determinante, pese a todo, en la generación de espantos), lo que más llama la atención es el planteamiento argumental de varias de estas propuestas. Los pasajes propiamente dichos, así como los espectáculos en discotecas y salas de cine, son más parcos en este sentido; en cambio, las funciones realizadas en casas rurales, restaurantes y calles parten de una base narrativa totalmente definida, apuntada en el breve texto que acompaña a cada presentación. He aquí el que encabeza la opción para alojamientos rurales, titulado Llantos en la noche:

Hace algunos años la residencia para niños dirigida por un matrimonio joven, Ágata y Manuel, cerró por motivos que aún hoy en día son desconocidos. / Ágata convirtió aquel pequeño edificio en una casa rural y recibe con amabilidad a sus invitados. / En el pueblo todo el mundo habla de esta situación, unos aseguran que Manuel abandonó el lugar sin dar una sola explicación, en cambio otros, creen haberle visto muchas noches inmóvil ante las puertas de la casa. / La enfermera, Ángela, que cuidaba de los niños pasa las tardes sentada en el jardín, siendo feliz al observar a Bruno cuidar las plantas del lugar. / Él es uno de aquellos chicos que crecieron en la residencia. Ahora, es junto a la dueña el encargado de recibir y atender a los visitantes, un muchacho al que la oscuridad de la noche le sigue aterrando. / Al caer el sol se escuchan los llantos incesantes de un bebé, y es entonces cuando Bruno es capaz de pronunciar solamente una palabra: AYUDADME.

Holgará apuntar las resonancias a títulos señeros del Séptimo Arte, con El orfanato (Juan Antonio Bayona, 2007) y Al final de la escalera (The Changeling, Peter Medak, 1979) a la cabeza. Otra propuesta paralela a esta, realizada con éxito en Salamanca en el año 2009, es Fear 2.0, organizada en torno a un presunto experimento sobre el miedo y nutrida, se nos informa, de referentes modernos como Saw (James Wan, 2004) y Hostel (Eli Roth, 2005). ${ }^{14}$ El montaje en el restaurante -Una cena en el infierno- es, en comparación, un poco más esquemático, pero igualmente asentado en una intriga y unos sujetos concretos, que interactúan entre ellos y con los asistentes: el misterioso dueño, una de sus hijas -que sufre un extraño ataque de epilepsia ante la desconcertada concurrencia-, un cocinero ensangrentado, etc. En cuanto a los espectáculos ofrecidos en la calle, se trata, en realidad, de visitas teatralizadas, donde se

14 http://www.redteatral.net/noticias-fear-2.0-842 [Consulta: 17/10/14]. 
hibridan los géneros y que, inspiradas en episodios históricos, obedecen igualmente a un hilo argumental.

En la actualidad, la «Factoría de Terror» continúa con sus proyectos, trabajando para el cine, pero sin desatender las artes escénicas. Buena muestra de su polifacética actividad es el «festival de miedo» «Hall of Terror», también anunciado en el sitio y en el que se ofrece de todo: desde talleres de maquillaje hasta proyecciones de cortometrajes, pasando por cuentacuentos y espectáculos como los que acabo de citar. Recientemente, se ha visto a sus miembros en el Festival Internacional de Cine Fantástico de Madrid «Nocturna», al que se encuentran vinculados desde su creación (2013). Sus intervenciones consistieron, eminentemente, en performances más o menos improvisadas, con caracterizaciones prototípicas y protagonizadas por emblemas como Leatherface.

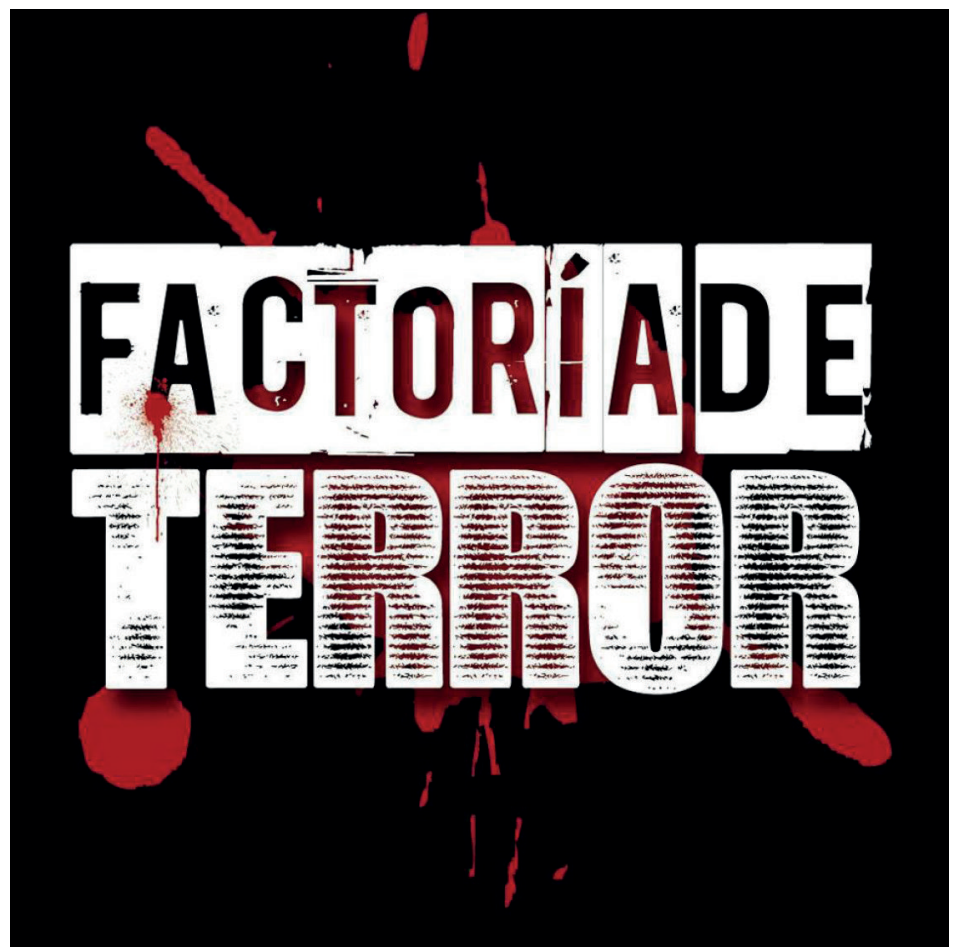

Figura 1 
Pasando al otro referente escogido -Psicofobia-, se presenta como un «espectáculo extremo», reminiscente del aludido Nyctophobia, en el que «los espectadores entrarán en un ambiente que jamás puedan [sic] vivir en la realidad, situaciones que solo podrán imaginar en las peores de sus pesadillas, un espectáculo donde no hay distancia entre el espectador y el actor». Liderado desde 2009 por un «equipo creativo» de composición familiar y subvencionado por la Concejalía de Juventud del Ayuntamiento de Huétor Vega, descuella por lo trabajado de sus efectos, especialmente el maquillaje. Como leemos en la web del evento, su celebración tiene lugar en fechas cercanas a Halloween y cada año presenta una temática distinta, ${ }^{15}$ en un formato que incluye proyecciones e interacción con actores primorosamente caracterizados. En cuanto al espacio, en los últimos tres años se ha realizado el Pabellón Deportivo «La Libertad»: en su interior se ofrecían 8 pases de 45 minutos, en grupos de no más de 5 personas; como se indica, todas habían de tener cumplidos los 18 años para participar; detalle que, en un ámbito como en el que pisamos, no es en absoluto baladí. Tradicionalmente asociadas a la adolescencia -aun a la más tierna-, los pasajes del terror de último cuño van más allá de los sustos intrascendentes y la diversión dominical, enfrentando al participante a situaciones verdaderamente desasosegantes, en las que siente peligrar su integridad física; la idea es tensar las cuerdas al máximo, hasta el punto de que, en ciertos casos, los participantes disponen de una safety word para detener el espectáculo (caso del mencionado Blackout). Como se verá, esta interactividad extrema es decisiva con relación a los elementos perturbadores.

Volviendo a Psicofobia, hay que subrayar la importancia de la oscuridad, determinante en una de las modalidades vistas, pero igualmente clave en todas las otras, siendo uno de los elementos que más han aterrorizado al ser humano desde su origen. A la inquietud derivada de ella se añade otra más explícita, emanada de escenas sangrientas o desagradables y aun de persecuciones de engendros. Todo ello, como se lee en una nota de prensa sobre la edición de 2009, «llevó a muchos al borde del infarto».

15 En 2012, por ejemplo, se ambientó en una catástrofe nuclear, mientras que en 2011 la historia giraba en torno a una fotografía que los asistentes debían localizar. Los datos proceden de sendas notas de prensa alojadas en la página web del evento (http://www.psicofobia.com/ [Consulta: 17/10/14]). 


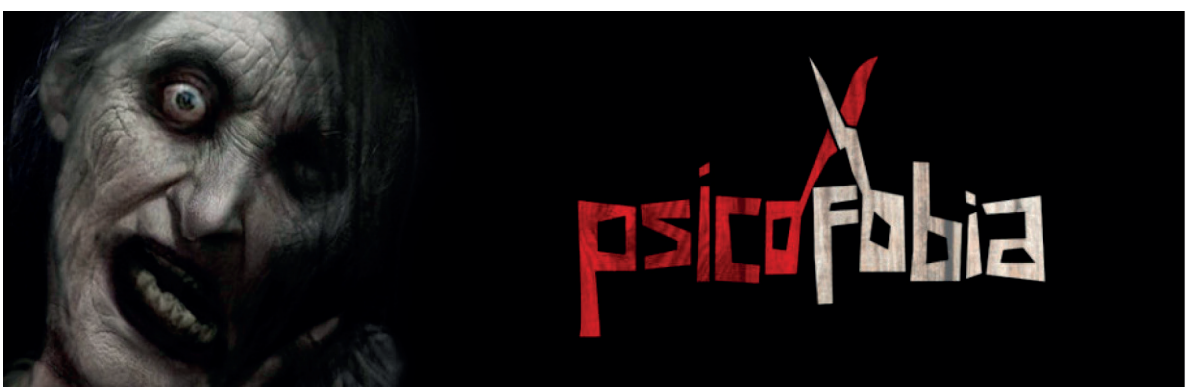

Figura 2

Estos son solo dos exponentes de un panorama mucho más rico y polimorfo, en el que, por desgracia, no me puedo entretener. Baste con aludir someramente a otras propuestas de gran interés. Entre las que poseen ubicación fija, destacamos «La Casa del Terror», ${ }^{16}$ la cual embarca a sus asistentes en un juego tipo cluedo, con multitud de personajes y misterios, cuyo objetivo consiste en deshacer una maldición; «La Casa de los Horrores», situada en las inmediaciones de Madrid y que propone un programa completísimo, desde una hora de duración hasta 22, con animaciones de todo tipo (incluso disfraces para los clientes); ${ }^{17}$ y «La Quinta del Melque» (Toledo), en activo desde 2003 y basada en «aquellas leyendas urbanas que todos hemos escuchado alguna vez y que en mayor o menor medida nos han impresionado [con] guiños a películas clásicas del género como Los otros, The Ring o La residencia».18

Por último, en lo relativo a espectáculos concretos, cito los de la compañía «Insomnia Corporation», tres de los cuales tienen lugar en un hotel de Barcelona y un cuarto -El secreto- en un bosque situado en la carretera de Andorra; este último, por cierto, propone dos niveles de espanto: «diversión» $\mathrm{y}$ «terror extremo».19 A estas alternativas añado, para terminar, las de «Creaciones Interactivas»: El psicópata y la aún en marcha Coleccionista del Mal, de ubicación indeterminada de la capital, solo revelada una vez hecha la reserva, y en la que se invita a los espectadores a contemplar la colección privada del Dr. Héctor Luna, formada por objetos malditos. ${ }^{20}$

\footnotetext{
16 http://www.lacasadelterror.es/ [Consulta: 17/10/14].

17 http://www.casadeloshorrores.com [Consulta: 17/10/14]/.

18 http://www.viajesconimaginacion.com/web/nuestrosviajes/show/id/13.html [Consulta: 17/10/14].

19 http://www.hoteldeterror.com/ [Consulta: 17/10/14].

20 http://www.coleccionistadelmal.com/ [Consulta: 17/10/14].
} 


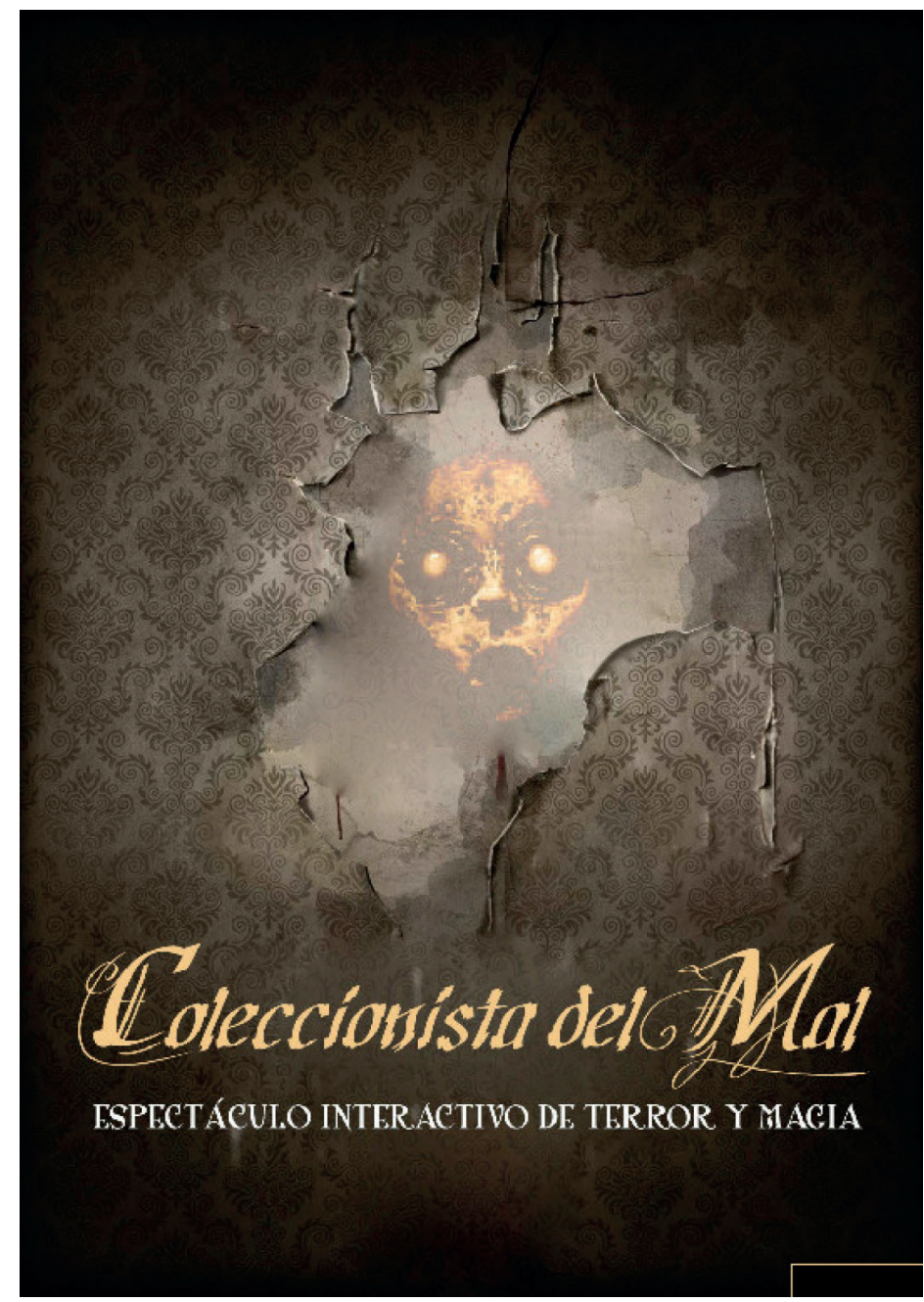

Figura 3

En fin, confío en que este apresurado resumen dé idea de la cada vez más acusada presencia de esta especie de espectáculos en la geografía española. Tan honda popularidad hace no solo oportuno, sino urgente, un diagnóstico teórico que tenga en cuenta su especificidad teatral y sus vínculos con la tradición del terror y lo fantástico. En las páginas que siguen no me fijaré en ningún caso en concreto. Creo, de cualquier manera, que mis observaciones serán aplicables a todas las formas. 


\section{LEGITIMACIÓN DE LA TEATRALIDAD DE LAS CASAS DEL TERROR}

En verdad, poca gente asociaría los túneles del terror con el teatro tal y como lo entendemos convencionalmente; la mayoría de nosotros señalaría un nexo con otros fenómenos de índole también espectacular, pero apenas dramática, como son las fantasmagorías o los freak shows (con los que, a todas luces, están emparentadas... si bien más en la materia que en los procedimientos formales). A poco que nos paremos a pensar, veremos, no obstante, que reúnen varias de las condiciones que cualquier teórico señalaría como esenciales de este multiforme, fecundo y milenario modo de representación. Independientemente de las semejanzas más obvias y materiales -maquillaje, vestuario, iluminación, escenografía, sonido-, contamos con un principio irrenunciable en toda expresión dramática: la idea de ficción; no solo eso: la ficción articulada a través de una representación con actores y otros elementos que figuran unos personajes, un espacio y un tiempo determinados. En efecto, al igual que en la escena tradicional, se produce el desdoblamiento de las unidades representantes, entre un plano real (escénico) y otro ficcional (diegético), generando, en la síntesis, el magma específicamente dramático (cfr. García Barrientos, 2001: 38). Esta hibridez constituye, como digo, una de las condiciones sine qua non de la actividad teatral, hasta el punto de que se puede decir que es, con la presencia del público, la única imprescindible para que haya teatro.

A este primer punto se une otro no menos básico, hondamente relacionado con el recién expuesto, y que nos retrotrae a los orígenes mismos de la actividad escénica: la participación directa del espectador. En los años 60 del pasado siglo, profesionales como Grotowski o Brook reclamaban la vuelta del teatro a su condición de ceremonia y, por ende, la restitución de un papel activo al público: en ello, decían, residía su «única posibilidad de sobrevivir, en contacto con las artes de masa industrializadas y en el seno de la tribu electrónica» (Pavis, 1996: 406). De algún modo, las casas del terror incorporan también este extremo y, por muy frívolo que pueda parecer, con una carga emocional comparable con la catarsis aristotélica: ¿qué es, si no, lo que experimentan los asistentes a un espectáculo de este tipo, más que una purificación a través del horror en sentido lato? El ingrediente lúdico no debe restar credibilidad a la atribución: desde los tiempos del Estagirita el teatro se concibe como simulación y, por tanto, como una expresión leve, susceptible de disfrute precisamente por la certeza de su falsedad. Otra cosa, claro está, son los contenidos morales y religiosos que subyacen a la tragedia griega; tampo- 
co estos, empero, se han mantenido iguales a lo largo de la historia del teatro en Occidente, llegando a desaparecer en los ámbitos más complacientes y aburguesados, reemplazados, como sugiere Pavis, por la intrascendencia de la modernidad.

Sin duda, hay factores que ponen en tela de juicio estas asunciones preliminares: los puristas dirán que la intervención del público, en calidad de participante y cocreador de la acción, niega la sempiterna barrera entre escena y sala, irrumpiendo en un territorio inespecífico. Más aún: también se argüirá que el carácter escasamente articulado del espectáculo, privado de la figura de un director de escena o un libreto previo, abierto a espacios múltiples y a veces incluso carente de personajes y diálogos, desemboca en un ejercicio trivial en el plano escénico. Reconociendo el carácter extremo, insólito y festivo de este universo, no me parecen razones suficientes para invalidar los nexos establecidos o desacreditar su estatus como actuación de pleno derecho; todo lo iconoclasta o inusual que se quiera, todo lo mediocre que se pueda imaginar -como que la mayoría de las veces no la llevan a cabo intérpretes profesionales-, ${ }^{21}$ pero enmarcada, en su parte más sustancial, dentro de las exigencias del modo.

La heterodoxia de las casas del terror se puede -y seguramente se debeponer en relación con la de la escena posdramática, prefigurada por los nombres arriba citados y representada en España por artistas como Sara Molina, Roger Bernat, Rodrigo García o Angélica Liddell. Dejando a un lado dimensiones de corte filosófico, social o político - que poco tienen que ver con la naturaleza teatral del producto-, la comparación se me antoja de lo más ajustada y esclarecedora, y menos gratuita de lo que parece. ${ }^{22}$ En ambos casos se trata de exponer a los espectadores a emociones límite, que cuestionen su seguridad como espectadores pasivos (pensemos en Insultos al público, de Handke, uno de los máximos emblemas de la violencia ejercida sobre la sala). Ya sin mencionar los motivos y recursos empleados -que también presentan jugosas coinciden-

21 No siempre es así, por supuesto. Valga rescatar, a este respecto, las declaraciones de José Antonio Guerra, profesional del sector; a la observación sobre el hecho de que la gente no se espera encontrar actores de verdad en un túnel del terror, afirma: «Esa es una de las mayores desventajas que tenemos: el poco reconocimiento. Pero te digo que no he pasado un casting más curioso, y más duro, para trabajar en los pasajes del terror de Port Aventura. A mí, por ejemplo, me hicieron interpretar la transformación de un hombre en lobo» (Red Teatral, s. a.). Por su lado, Zoraida Marín compara las actuaciones de estos espectáculos con el teatro de calle, con el que compartirían «un público que pasa de largo» (ibid.).

22 Sintomáticamente, el principal teorizador del teatro posdramático se refiere a las obras de Reza Abdoh, uno de los autores clave de esta línea, como "grotesque haunted house spectacles» (Lehmann, 1998: 91). La identificación se basa en el formato de las piezas, basadas en una sucesión de cuadros sin orden aparente; ello no quiere decir que el contenido no guarde también semejanzas. 
cias-, hay un factor determinante para lograr este fin: la igualación de espectador y personajes en un mismo nivel de realidad, es decir, la integración pretendidamente total de aquel en el fenómeno de la representación. A esto se podría objetar que mientras que las funciones posdramáticas buscan la destrucción de la quimera ficcional, la pretensión de los túneles del terror es exactamente la opuesta: arrastrarnos a un universo donde lo sobrenatural se vuelve posible, llevando a sus últimas consecuencias la suspensión de la incredulidad de la que hablaba Coleridge. Pues bien, hasta eso se me antoja discutible: partiendo de la hipótesis de que siempre que hay representación existe un cierto grado de ficcionalidad o, en todo caso, simulacro, ${ }^{23}$ es dable afirmar que el encuentro entre los dos polos se produce en un lugar muy próximo y en circunstancias similares: desde instancias contrapuestas, no cabe duda, pero, aun así, coincidentes. Cabe, por lo demás, preguntarse qué es lo que se activa en el espectador en un pasaje del terror: si su faceta ficcional -siendo así que su reacción afectiva es un mero fingimiento, paralelo al que experimenta cuando observa una película y da un respingo- o su personalidad verdadera, genuinamente temerosa de su integridad. En esta irreductible dialéctica es donde también se mueve, de donde saca su fuerza, el teatro posdramático; ${ }^{24}$ digo más: el teatro en su totalidad. Tal es el sentido último del concepto de denegación (cfr. Pavis, 1996: 121-122): creer y no creer lo que ocurre en escena, candidez y escepticismo en perfecta síntesis. Al respecto, es interesante la observación de Elam (1981: 108; cursiva del autor) cuando, en alusión a la fórmula de Coleridge, desaprueba la ingenuidad total del público:

On the contrary, disbelief -i. e. the spectator's awareness of the counterfactual standing of the drama- is a necessary constant, since it permits him to judge and enjoy what is represented according to less literal standards that he might apply to his own social experiences.

En pocas palabras: la conciencia de la ficción es un punto absolutamente irrenunciable de la representación, tanto como la (fingida) creencia

23 Como ya decía Bettetini (1975: 78) hace unos cuantos años: «Cuando se habla o se escribe, se construye un espacio "otro" con respecto al espacio de la realidad, aun en aquellos casos en que los mensajes hagan una referencia simplemente denotativa, descriptiva con respecto a una cierta objetualidad-referente». Sobre el caso específico de la escena posdramática, cfr. García Barrientos (2008: 34).

24 «When the staging practice forces the spectators to wonder whether they should react to the events on stage as fiction (i.e. aesthetically) or as reality (for example, morally), theatre's treading of the borderline of the real unsettles this crucial predisposition of the spectators: the unreflected certainty and security in which they experience being spectators as an unproblematic social behaviour» (Lehmann, 1998: 104). 
en lo que estamos contemplando. Como dice García Barrientos (1980: 101), «lo específico de la recepción teatral se encuentra en la oposición, irreductible, entre las relaciones de identificación y distancia»; y más abajo: «El público no solo percibe dos caras -actor y personaje- sino que las percibe desde dos perspectivas, real una y ficticia la otra» (1980: 107). Sin tal complicidad, sin este pacto entre actores y espectadores -por inaparente que sea-, deja de existir el teatro, pasando a ser un anodino y unidimensional episodio de la vida cotidiana, para el que no haría falta la mirada de un público; o peor aún, derivando en una actitud patológica, incapaz de diferenciar la realidad de la ficción. De esta eventualidad se hace eco el mismo teórico en la siguiente cita:

El actor que se transformara en su personaje o se identificara con él de manera absoluta, cambiaría su condición por la de enfermo mental de histrionismo, igual que el que no consiguiera en absoluto encarnar al personaje o se distanciara totalmente de él, podría ejercer de orador, pedagogo o narrador de historias, pero no de actor de teatro. Lo mismo puede decirse del espectador, tanto cuando concede todo el crédito de la realidad a la ficción, y quiere avisar a Romeo de que Julieta no ha muerto, como cuando no llega a percibir sino la cara real o representante del espectáculo, sea por recalcitrante mala fe o, más probablemente, por ineptitud de los ejecutantes (1980: 102).

Así pues, tanto en las casas del terror como en las piezas posdramáticas el espectador deviene un integrante más del espectáculo, participando del mismo colectivamente (o a menudo también individualizándose, cuando es llamado al escenario o interpelado directamente); no solo eso: desechada su identificación con los sujetos escénicos, despliega sus propias emociones. Como decía, uno de los rasgos que más define a las casas del terror es el paso del desasosiego por delegación, basado en la sintonía con la subjetividad de los personajes (de lo que se nutren, principalmente, la literatura y el $\operatorname{cine}^{25}$ ), a la experiencia netamente personal. Todo ello haría pensar en la disolución de barreras ontológicas. Hay que reiterar, sin em-

25 En el cine, aun así, habría que apuntar algunas reservas a este respecto, pues si bien es verdad que nuestra inquietud procede, en principio, de la identificación con la vivencia de los aterrorizados protagonistas, no lo es menos que hay espantos cuya efectividad se funda en que somos los espectadores los únicos que los sufrimos. Como dice Sergi Sánchez (2002: 312), hay casos en que nos asimilamos a la perspectiva del asesino, y no de la víctima, y otros, más interesantes para mi argumentación, en que «los movimientos de la cámara subjetivos no obedecen a ningún otro objetivo que el de perturbarnos o liquidar nuestro sentimiento de seguridad y ubicación». Carroll (1990: 194208), a este respecto, habla de relación «asimétrica» entre la experiencia del protagonista y la nuestra, cuestionando la tan manida identificación. Así visto, el cine constituiría un término medio entre la narrativa y el modelo que aquí se define. 
bargo, que nada de esto es extraño a los mecanismos del modo: el público, en mayor o menor medida, está siempre dramatizado; bien mirado, es un requisito ineludible, también asociable a la idea de denegación: así, aun cuando nos sentamos pasivamente en la sala de butacas y observamos tranquilamente el espectáculo, hay una parte de nosotros que se ve absorbida por el torbellino de la escena, que forma parte de él o, como poco, interactúa con el mismo. Lo único que hacen tanto los túneles de terror como las propuestas más rompedoras es llevar este desdoblamiento al límite, desembarazándose de la figura intermedia del personaje y aprovechando al máximo la denominada apelación al público: del tipo que García Barrientos (1980: 80) llama dramático, en el caso de las casas del terror -los sujetos de la escena se dirigen al respetable en cuanto entes de ficción, convirtiéndolo, por tanto, en uno más-, y de corte escénico, en el de los espectáculos antifigurativos -los actores le hablan al público desde su condición de intérpretes reales, integrándose, con ello, en el mundo factual del espectador... o más bien creando un espejismo de ello.

El respeto que, pese a todo, guardan estas formas con relación a las convenciones escénicas ${ }^{26}$ se pone especialmente de relieve al considerar nuestra supuesta libertad de movimiento o el margen de improvisación: da igual cuánto se encarezcan dichos extremos, nunca podremos ser dueños del espectáculo ni hacer que avance a nuestro antojo. Vale que ciertas modalidades permiten diversas alternativas en cuanto al recorrido o el desarrollo de la acción. Existe, aun así, un plan prefijado, en términos temporales, espaciales, escenográficos e interpretativos; todo lo holgado que se quiera, pero palpable e indiferente a nuestra condición (de mirantes, al fin y al cabo). Ello es por varias razones ( $\mathrm{y}$ ahora me refiero en exclusiva a nuestro objeto): dando por sentado el deseo de evitar el caos y los posibles abusos, la más obvia sería de carácter mercantil; pagada una entrada -o contratado un pase- y pactadas unas condiciones, la representación ha de contar con una duración máxima, que posibilite nuevas entregas en un periodo convenido. A este motivo práctico se unen otros de índole organizativa y, en ciertos casos, narrativa. No pienso en los clásicos túneles de feria, desprovistos de una lógica argumental, basados en la sucesión de cuadros y escenas arquetípicos, sino en aquellos espectáculos asentados en una línea discernible, con una acción mínimamente trabada.

26 Sobre la obediencia del teatro posdramático a una ideal universal de teatro, cfr. Carrera Garrido (2013), análisis de la dramaturgia de Rodrigo García a la luz de la teoría dramatológica. 
«La mayoría de pasajes del terror tienen que tener un argumento, un hilo conductor para que el público se sumerja en la historia, y le llegue mucho más todo lo que hacemos», dice Iván Meylán (Red Teatral, s. a.), responsable de shows de Halloween en Port Aventura. En esta atención a una trama se aleja nuestro objeto de la posdramaturgia -una de cuyas consignas consiste, justamente, en desterrar la noción de intriga de la escena ${ }^{27}-$, aproximándose, en cambio, al teatro convencional y, en concreto, a la línea de lo fantástico y terrorífico. ${ }^{28}$ Por supuesto, no se trata de algo indispensable, ni en el modo dramático ni en cualquier otro tipo de ficción. Ello no obsta para argüir que la obediencia a un hilo narrativo nos acerca a una ortodoxia con la que el público general habrá de sentirse más cómodo, más en casa, y menos reticente a ver las casas del terror como una opción más del arte mimético y, en particular, del espectro dramático.

Tengo para mí que el factor que más resistencia ha de causar a la hora de barajar esta idea es el ingrediente lúdico y mercantil que mencionaba más arriba. Frente a la supuesta seriedad e ínfulas artísticas de modelos como los mentados -todos ellos, aun los más rupturistas, aceptados dentro del coto escénico y abordados por la academia-, diríase que los túneles del terror, exclusivamente destinados a un disfrute efímero y adrenalínico, merecen contemplarse dentro del arte de Talía tanto como un salto en paracaídas o la bajada de un río haciendo rafting. En realidad, es el mismo destino que se les ha venido deparando a otras manifestaciones de tipo popular, como el teatro de variedades, la revista o, en el terreno de lo fantaterrorífico, el Grand Guignol. Cualquiera estará de acuerdo en que se trata de prejuicios culturalistas, y no de razones fundadas en la inespecificidad del producto. Es más: estimo justo equipararlos con las reservas que desde tiempos inmemoriales han suscitado, tanto en la universidad como entre autores y receptores cultos, las modalidades de la ciencia ficción, lo fantástico y el terror, especialmente en el entorno español. Recientes aportaciones -como el presente monográfico-demuestran que la reticencia comienza a ceder, también en nuestro país; aún queda, sin embargo, un largo camino por recorrer para que productos de este tipo sean considerados en su inmanencia y en atención a unas categorías específicas.

27 De nuevo, Lehmann (1990: 68) no deja dudas al respecto: «Effectively, the category appropriate to the new theatre is not action but states. Theatre here deliberately negates, or at least relegates to the background, the possibility of developing a narrative».

28 En este orbe el soporte argumental goza, en efecto, de un gran predicamento. «Existe una curiosa coincidencia entre los autores que cultivan lo sobrenatural y aquellos que, en la obra, conceden especial importancia al desarrollo de la acción», escribe Todorov (1970: 118). Por su lado, desde la vertiente terrorífica, afirma King (1987: 265): «Story has always been the abiding virtue of the horror tale». 
Rastreado el sustento escénico de las casas del terror, es lo que se dispone a acometer el resto del artículo: la caracterización de su funcionamiento a la luz del marco fantástico-terrorífico.

\section{LUGAR DE LO FANTÁSTICO Y TERRORÍFICO EN LOS TÚNELES DEL TERROR}

Resulta complicado, pero a la vez estimulante, indagar la relación que se establece entre los asistentes a una casa del terror y los elementos desplegados para infundirles miedo. En páginas precedentes quedó clara la diferencia entre la implicación de un receptor literario o cinematográfico y uno que interviene en esta forma de espectáculos: cuando en una película o en un libro se nos anima a sumergirnos en el mundo de ficción, lo que en realidad se nos está diciendo es que nos identifiquemos con la vivencia de un sujeto autónomo, existente en otro nivel de realidad y al que le ocurren cosas que están totalmente fuera de nuestro alcance. En contraste, en el tipo de experiencias aquí contempladas dicha inmersión cobra todo su sentido; en ellas, ya lo advertí, la cercanía propiciada por la inmediatez del modo escénico trasciende los filtros de las variedades escriturales. Es un matiz que condiciona enormemente la naturaleza de la reacción afectiva en cada caso; sobre la narrativa y el cine, dice Savater (2002: 323-323):

La experiencia de esta especie de subidón vital que te da el peligro o la amenaza de muerte, acompañada de la posesión de la certeza absoluta de que el peligro no es real, que no te está rondando una amenaza verdadera, es el secreto del cine de terror, de las historias de los cuentos de miedo. Esta mezcla de un miedo suficiente para sentirse vivo pero no como para sentirse en verdadero peligro, porque no hay tal, tiene un punto delicioso. Porque a pesar de que estemos convencidos de que el monstruo de la pantalla y lo que estamos leyendo no es una amenaza real, sin embargo instintivamente reaccionamos, en cierta medida, como si estuviéramos amenazados.

Se trata de una tesis habitualmente reiterada en las reflexiones sobre lo fantástico y terrorífico, y que contribuye a explicar el placer derivado del terror-arte. La clave está en la simulación de ese peligro, ante el que respondemos como si fuera real. En su capítulo sobre la relación con la ficción, donde intenta razonar el porqué de tan paradójica respuesta emocional, se indigna Carroll (1990: 346, n. 21) con los teóricos que comparan la lectura o el visionado de una pieza terrorífica con un viaje en montaña rusa, como «clase de juego primordial con la muerte»; según él, la analogía es «completamente in- 
sensata y no explica nada», pues, mientras que esta atracción sí entraña un riesgo -que los mecanismos de seguridad fallen y nuestro cuerpo acabe aplastado contra el suelo-, ninguna película o libro dan cabida a una amenaza remotamente similar,; ${ }^{29}$ en su lugar, se produce una recreación de la misma, un sucedáneo erigido sobre un complejo proceso psicológico y crucialmente condicionado por la naturaleza ficticia de la pieza.

Esto se aplica, como digo, a la narrativa y el cine, universos cerrados e independientes del nuestro; por su lado, las casas del terror, y el teatro en general, abren la puerta a una modalidad intermedia en lo que a la réplica emocional atañe. Tampoco aquí -al menos en principio- cabe la posibilidad de un peligro efectivo. El carácter híbrido de la representación propicia, aun así, una fructífera ambigüedad: por supuesto que se trata de actores encarnando a monstruos y psicópatas; claro no son más que efectos especiales esos aullidos tan estremecedores; no podemos, pese a todo, dejar de preguntarnos qué pasaría si uno de los intérpretes perdiera la cabeza y agrediera de verdad a los asistentes, o si la máquina que produce humo provocase un cortocircuito y se declarara un devastador incendio ¿En dónde nos situaríamos en ese caso? Parece obvio que en el plano real: en ese punto no quedaría ninguna duda, la ilusión se habría roto. Pero, ¿y antes? Como avanzaba más arriba, es legítimo preguntarse qué es lo que causaba el temor previo a la irrupción de la pavorosa realidad: ¿la simulación -como en el papel y el celuloide- o la posible factualidad de los hechos y criaturas presenciados? La respuesta se perfila ambigua, en consonancia con la dialéctica sobre la que se asienta el teatro; en este sentido, se puede decir que las casas del terror funcionan de acuerdo con una lógica muy similar a la que Todorov (1970: 18-30) atribuía a la literatura fantástica: la vacilación como fundamento, la indecisión entre una vía y otra (realidad/ficción) y, sobre todo, la imposibilidad de decantarse por una interpretación terminante.

Como se comprenderá, este constante juego con los límites de lo real y lo ficticio plantea no pocos dilemas respecto a la percepción de los factores destinados a suscitar la emoción deseada. Dado que muchos de ellos se inscriben en la región de lo sobrenatural, son del todo inasumibles por la episteme del espectador. Ello no conduce a inhabilitar el pacto que tácitamente se firma cuando se paga un billete y se traspasa el umbral, ni a invalidar la dinámica

29 Los casos de trastornos o aun ataques al corazón causados por la exposición a una tensión o explicitud extremas -recuerdo ahora el de un espectador que falleció durante la proyección de Hannibal (2000)- habrían de ser considerados desde otra perspectiva, como efectos secundarios de dicha exposición, y no como resultado directo de nuestros tratos con el mundo y las criaturas de la ficción (al que, recordemos, solo accedemos mediante la empatía con las circunstancias de los protagonistas). 
distintiva de lo fantástico; según De Beni (2012: 71): «Esta "confusión de la escena con la realidad" es justamente lo que puede desencadenar el efecto fantástico»; es la misma ilusión consciente que el crítico asocia a las fantasmagorías (2012: 91). Hay que advertir, aun así, que en muchos casos el miedo emana de extremos que en nada tienen que ver con la ontología disruptiva de los ingredientes empleados. Como apunta Ferreras (2003: 19): «El horror crea la tensión narrativa a través de la representación de lo horrible, de lo sangriento, de lo doloroso, y no a partir de la oposición entre realidad e imposibilidad»; elocuentemente, el recién mentado Todorov (1970: 35) situaba la literatura de terror en los márgenes de lo extraño. Al respecto, merece la pena rescatar dos oposiciones de amplio bagaje en los estudios sobre lo terrorífico: terror frente a horror, por un lado, y miedo físico frente miedo metafísico, por otro.

Empezando por el segundo duplo, Roas (2011: 95) afirma que el miedo metafísico es la modalidad característica de lo fantástico, su efecto/afecto principal. Al terror, en cambio, se acogen las dos variantes. No en vano, la literatura gótica -germen de la estela terrorífica- abunda en historias sin componente sobrenatural o cuya efectividad se basa en horrores perfectamente factibles en la vida real, fundados en «la amenaza física, la muerte y lo materialmente espantoso». Nuestro objeto de estudio no es una excepción: en las casas del terror se combinan los maleficios y apariciones con episodios de simple crueldad o cuadros que no buscan más que revolver las tripas al respetable. El primer grupo se enmarca, sin ningún género de dudas, entre la materia fantástica; en cuanto al segundo, tiene un carácter más visceral, a menudo vinculado con el mundo del gore. En este punto conviene referirse a la otra oposición.

Expuesta por primera vez por Ann Radcliffe, distingue entre el miedo generado por la tensión e incertidumbre, y aquel otro producido por la contemplación directa de los horrores, con frecuencia identificados con escenas de violencia o estampas monstruosas (cfr. Wright, 2007: 46-50). Stephen King (1987: 23) establece en este segundo polo una nueva división, entre la mera explicitud y la repulsión, mostrando su censura hacia esta última, patrimonio, según él, de la ficción barata. Es una postura generalizada entre numerosos cultivadores y aficionados al género: el miedo debe cimentarse en una situación perturbadora por su indeterminación, donde la imaginación del receptor juegue el papel más importante. Ya Lovecraft (1927: 8), al comienzo de su clásico estudio, expresaba su preferencia por la sugerencia y la creación de una atmósfera, condenando lo demasiado patente y hasta cotidiano; paralelamente, ensalzaba el miedo a lo desconocido e incognoscible-el horror cós- 
mico, como él lo llamaba- en detrimento de los excesos de hemoglobina y fisicidad.

Las casas del terror plantean un caso peculiar respecto de estas categorías. Teniendo en cuenta lo dicho sobre la proximidad entre actores y espectadores y el carácter tangible de los espantos, se hace necesario adaptar cualquier consideración previamente aplicada al mundo de la literatura y el cine. No me parece, por ejemplo, que se pueda establecer un nexo relevante entre la literatura terrorífica y el objeto de análisis, más allá de los motivos temáticos. Por más que reconozca el legado de nombres como Poe, Stoker o el recién mencionado Lovecraft, es innegable que su influencia se canaliza a través del orbe fílmico (o, como poco, del cómic): la Universal y la Hammer como máximos referentes estéticos, pero también creadores de arquetipos como Tobe Hooper, Wes Craven, John Carpenter, Clive Barker o David Cronenberg. El peso del cine es explicable por varias razones: en el plano más superficial, habría que señalar el sesgo hondamente comercial de la industria cinematográfica, incluida en la más amplia del entretenimiento (donde también estarían los túneles del terror); comercialidad, por cierto, que también se atribuye al propio género, uno de los favoritos del público palomitero, ese que solo va al cine para pasar un buen rato y no le importa que le cuenten siempre la misma historia. No entro en calificaciones de ningún tipo: únicamente constato un vínculo que creo indiscutible, basado en la explotación comercial del producto.

El otro nexo es, sin duda, más interesante para los propósitos de este artículo. Remite al carácter audiovisual de ambos modos. Quizá sea perogrullesco o roce la aporía, pero ni el cine ni las casas del terror serían nada sin la imagen y el sonido; entendámonos: el tratamiento de los temas, así como los motivos barajados, juegan un papel determinante en la creación de desasosiego; son, pese a todo, los componentes visuales y sonoros los que generan los mayores efectos. Una vez más, se podría argüir que el acierto reside en lo insinuado, en lo entrevisto, y no en lo evidente; pues bien, incluso lo entrevisto necesita de una visión efectiva, de una manipulación de la imagen que propicie la ambigüedad. No hablo, pues, de explicitud; me refiero a algo mucho más complejo: a la posibilidad de jugar con los sentidos del espectador, de confundirlo con lo que cree estar presenciando e inducirle estados de ánimo de manera sibilina, mediante recursos totalmente inalcanzables para la narrativa.

Por supuesto, el juego sensorial comporta un factor de subjetividad que, como decía, es irrealizable en la escena (a no ser mediante expedientes 
inespecíficos): ni siquiera en los pasajes del terror es posible dirigir la percepción del espectador. Como sabemos, no obstante, en este contexto la subjetividad queda relegada por la experiencia personal, y ahí es donde de verdad cobran protagonismo los elementos audiovisuales, la plasticidad del espectáculo. Conectando con lo que apuntaba en una nota al pie páginas atrás, hay en el cine planos y escenas exclusivamente destinados a la contemplación de la audiencia. Eso las acerca a nuestra área de interés; hay algo, con todo, que aún las diferencia, y de forma crucial: la tantas veces glosada interactividad; mejor aún: la posibilidad de sentir en toda su dimensión aquello que se encuentra ante nosotros. En una película se pueden contemplar horrores de todo tipo sin que nada de lo que desfila por la pantalla establezca contacto físico real: lo vemos y lo oímos, pero no lo olemos ni podemos palparlo... ni saborearlo. En un túnel del terror, por el contrario, se plantea esta contingencia y, aunque la mayoría de las veces no llega a realizarse -como que, por lo común, a los actores les está terminantemente prohibido tocar a los asistentes-, el solo pensamiento incorpora un grado de inquietud que no tenemos en el cine $y$, mucho menos, en la narrativa. ${ }^{30}$

Volviendo, entonces, a las dos oposiciones arriba glosadas, debemos repensar el lugar otorgado a cada extremo. En un medio basado en la proximidad física, está claro que la categoría de horror adquiere un nuevo significado, incomparable con el que posee sobre una hoja de papel o en el celuloide: las alternativas son demasiado suculentas como para no sacarle partido; y lo mejor es que no se trata de un abuso: precisamente en ello radica su especificidad. Considérese, por lo demás, que el estatus palpable y sentible de las casas del terror no conduce, necesariamente, a la explicitud o el recargamiento de maquillaje, con miras a atacar el buen gusto del público. Al contrario, muchos espectáculos se basan en la creación de un clima de turbación, mediante elementos mínimos, que, si bien se asientan en los sentidos, no apuntan a la saturación ni se entregan a lo repulsivo; fomentan, más bien, la idea de un mal acechante, que en cualquier momento puede manifestarse amenazadoramente.

Los polos de terror y horror se ven, por tanto, fundidos en las propuestas escrutadas. Desde luego, siempre habrá un elevado número que se incline por lo repugnante y exhibicionista, alejándose del primer extremo. Esto, con todo,

30 El mero contacto con entes sobrenaturales o monstruosos, dicho sea de paso, constituye, según autores como Carroll (1987: 53-54) y Bloom (2000: 217), una de las piedras angulares de la emoción terrorífica; así, mientras que este último habla de un tabú, Carroll esgrime el miedo al contagio o la contaminación. 
no resulta tan grave como en un filme: como digo, se trata de un medio propicio a ello, que aun cuando recurre a opciones más sutiles, no puede dar la espalda al factor físico, sensorial (aunque solo sea por el trabajo con los efectos especiales y el maquillaje, a menudo lo más valorado por los asistentes). Esto es algo que entienden a la perfección los autores de teatro posdramático, con los que antes se relacionaba el objeto de estudio: en su voluntad de someter al espectador a emociones extremas, la abyección, incluso la obscenidad, se perfilan como herramientas de primer orden (cfr. Sánchez, 2006: 157-159). Su finalidad es ciertamente distinta a la de las casas del terror; no por ello deja de ser otra coincidencia elocuente, fundada en la reformulación de recursos que en otros dominios serían más censurables o carecerían del mismo potencial.

En el caso de los túneles del terror, su introducción supone, entre otras cosas, una seria relativización del papel de los elementos sobrenaturales en el conjunto. La misma apuntaba ya en el cine: más allá de que, a menudo, todo sea sangre y vísceras, los mecanismos para infundir miedo tienden a basarse más en el sobresalto que en la inquietud de inspiración fantástica. De nuevo, los más exigentes opinarán que se trata de una treta barata, que lo verdaderamente meritorio es perturbar con una buena historia y unas buenas interpretaciones, y no con pasajes aislados, casi siempre realzados por la imagen y el sonido; en esta tesitura, dirán, los motivos temáticos pasan a un segundo plano, siendo reemplazados por un mero respingo que puede provenir tanto de un demonio como de una inocente paloma o un gato (como tan a menudo ocurre).

Estos reparos tienen razón de ser en el entramado fílmico, que se ofrece al espectador como un producto cerrado, con un relato complejo y asentado en unos caracteres autónomos. Pasando a las casas del terror, vemos, en cambio, que el planteamiento se invierte un tanto. Al principio sostenía que el exceso de realidad en la escena entorpece la construcción de la diégesis y, más en concreto, el procesamiento de elementos sobrenaturales; en ello también interviene la eliminación de la subjetividad y, en general, de la sintonía con unos sujetos ficticios: de identificarnos con las creencias de estos, pasamos a ser nosotros mismos los que hemos de comulgar con las disrupciones de lo real. Qué duda cabe de que la aceptación es mucho más problemática en estos términos: por mucho que se nos empuje hacia la ficción, que se nos dramatice, siempre habrá una parte de nosotros que continuará anclada a la realidad, que percibirá la mentira por doquier. Como consecuencia, el pacto ficcional se debilita irremediablemente, complicándose la inmersión del espectador en el universo recreado y, con ello, obstaculizando la asunción de lo imposible o sobrenatural; la conciencia de la ficción a la que antes aludía es, en efecto, 
demasiado elevada como para trasladar al espectador del modo en que lo hacen una novela o una película. Ante tal hecho, los túneles del terror prefieren decantarse por la opción del sobresalto antes que el énfasis en los elementos fantásticos. No es síntoma de pobreza: al contrario, estoy convencido de que ahí, más que en cualquier otro lado, reside su mayor fuerza. Así, el asistente se mueve por el interior de una casa del terror sin pensar en lo sobrenatural, ni siquiera en que pueda ser despellejado por el mismísimo Jason Voorhees; lo que en realidad le perturba es el susto que le acelerará el ritmo cardiaco (o a la inversa: que puede llegar a parárselo). No se trata, en fin, de oponer el miedo físico al metafísico, ni siquiera de dirimir si es más efectiva la sugerencia que la explicitud, sino, como vengo diciendo durante todo el artículo, de enfrentarse a la irresoluble tensión entre lo real y lo ficticio, en un hic et nunc diametralmente opuesto a la alteridad ontológica de las escrituras; un contexto donde la presencia de lo fantástico deviene una mera convención, una envoltura estética tras la cual se esconde el verdadero meollo de estos espectáculos: la posibilidad (remota... pero no tanto como nos gustaría) de no salir vivos de ellos.

\section{CONCLUSIÓN}

En las páginas que anteceden se ha tratado, por encima de todo, de legitimar la consideración científico-teórica de un objeto tan poco asociado a la academia como son las casas del terror. La hipótesis, ya asentada en un artículo precedente (si bien aún no publicado), consistía en que estas constituyen un hábitat privilegiado para el terror escénico, más que una sala o escenario al uso, respetuosos con la cuarta pared. Partiendo de un vacío bibliográfico en verdad disuasorio, por el que me he visto obligado a consultar fuentes tradicionalmente desechadas por el discurso científico, el trabajo que aquí finaliza ha perseguido dos objetivos específicos, destinados, ambos, a incorporar estas manifestaciones a la reflexión y el debate universitarios.

La primera de estas metas implicaba el rastreo de la teatralidad inherente a las casas del terror. Tras una somera presentación de las diversas modalidades y un abreviado catálogo de ejemplos en el dominio español -en los que, debido a motivos de espacio y tiempo, no he podido detenerme demasiado-, la argumentación ha discurrido por los aspectos que aseguran la pertenencia de este fenómeno al reducto teatral. En mi análisis me he servido de una comparación que no por osada ha de ser menos ilustrativa: así, la participación directa del público en el espectáculo y su igualación con los 
sujetos de la escena me ha permitido vincularlo con algunas de las propuestas más rompedoras del panorama dramático actual. La intención de la analogía era doble: por un lado, aspiraba a establecer un nexo con formas que, pese a las tiranteces, son contempladas por la comunidad científica (con gran entusiasmo, en ciertos casos); de esta manera, pensaba, sería más fácil normalizar la consideración académica del objeto de estudio. A este fin primordial se unía otro de alcance más profundo: rastrear de qué manera y en qué condiciones se produce la recepción teatral, y si esta entra en conflicto con las bases del modo dramático. La conclusión ha sido que no: tanto las casas del terror como el teatro posdramático se nutren de un mecanismo previsto en la especificidad de esta forma de imitación -la apelación al público-, salvaguardando la hibridez propia de la representación escénica. No hay, pues, ruptura real de la figuración; solo el relevo de la identificación con los personajes - que pasan a un segundo plano- por la experiencia netamente personal.

Esta inversión de tornas tiene consecuencias determinantes en la consideración del factor fantástico y, en general, de los elementos empleados para desatar el miedo de los asistentes a un casa del terror. Remitiéndome a las oposiciones miedo metafísico/miedo físico y terror/horror, me he esforzado por demostrar que la interactividad connatural al objeto de interés relativiza el relieve que estas categorías tienen en la narrativa o, sobre todo, el cine. Crucialmente determinado por este, la insistencia en el componente sensorial adquiere en el contexto de los túneles del terror un sentido distinto al que ostenta en la pantalla, donde suele ser visto como un truco fácil. Aquí, la posibilidad de un contacto real, que problematiza los límites de la ficción, abre la puerta a una forma de espanto que poco tiene que ver con las disrupciones de lo fantástico o, en el polo del horror físico, con los excesos (simulados) de violencia o monstruosidad; que emana, más bien, del recelo por la propia integridad del participante. En la vacilación de este, incapaz de decidir si la amenaza es real o ficticia (independientemente de lo que le hayan dicho a la entrada), es donde este tipo de espectáculos alcanza su máxima expresión; una vacilación, así vista, equiparable a la que usaba Todorov para definir a la literatura fantástica, pero donde el factor sobrenatural ha quedado relegado a un mero motivo temático, privado del valor metafísico que ostenta en un filme y, especialmente, en una novela o un cuento.

En fin, las casas del terror constituyen, como se ve, un objeto fecundo tanto desde la perspectiva de los estudios teatrales como desde la óptica de lo fantástico y terrorífico. Estas páginas son una mera aproximación, que ideal- 
mente se completará en sucesivas entregas, centradas en otros aspectos, como la relación con la performance, el repertorio de motivos temáticos concretos o el flirteo con manifestaciones no artísticas y altamente controvertidas como el sadomasoquismo o aun las snuff movies. Queden de momento estas líneas como prueba de la riqueza del terreno auscultado.

\section{BIBLIOGRAFÍA}

Bettetini, Gianfranco (1975): Puesta en escena y producción significante, Gustavo Gili, Barcelona, 1977.

Bloom, Clive (2000), «Horror Fiction: In Search of a Definition», en David Punter (ed.), A New Companion to the Gothic, Wiley-Blackwell, Oxford, 2012, pp. 211-223.

$<$ http://dx.doi.org/10.1002/9781444354959.ch15 http://search.crossref.org/?q=BLOOM $\% 2 C+C l i v e+\% 282000 \% 29 \% 2 C+\% C 2 \% A B H o r r o r+F i c t i o n \% 3 A+I n+-$ Search+of+a+Definition $\%$ C2\%BB\%2C+en+David+>

Carrera Garrido, Miguel (2014): «Escalofríos en la escena: limitaciones del terror teatral», en Urszula Aszyk (ed.), Actas del Simposio Internacional «El teatro español como objeto de estudio a comienzos del siglo XXI» [título provisional], Universidad de Varsovia (en prensa).

(2013): «La destrucción o el teatro: la creación de Rodrigo García en la encrucijada entre escena posdramática y mímesis tradicional», Telón de fondo (Universidad de Buenos Aires), no. 18, pp. 79-110, disponible en <http://www.telondefondo. org/download.php?f=YXJjMi80OTAucGRm\&tipo=articulo\&id=490> [Consulta: $17 / 10 / 14]$

CArroll, Noël (1990): Filosofía del terror o paradojas del corazón, Antonio Machado Libros, Madrid, 2005.

(1987): «The Nature of Horror», The Journal of Aesthetics and Art Criticism, Vol 46, no. 1, pp. 51-59.

<http://dx.doi.org/10.2307/431308 http://search.crossref.org/?q=CARROLL\%$2 \mathrm{C}+\mathrm{No} \% \mathrm{C} 3 \% \mathrm{ABl}+\% 281987 \% 29 \% 3 \mathrm{~A}+\% \mathrm{C} 2 \% \mathrm{ABTh}+$ Nature+of + Horror $\% \mathrm{C} 2 \% \mathrm{~B}-$ $\mathrm{B} \% 2 \mathrm{C}+\mathrm{The}+$ Journ>

De BeNI, Matteo (2012): Lo fantástico en escena. Formas de lo imposible en el teatro español contemporáneo, Academia del Hispanismo, Pontevedra.

Elam, KeIR (1980): The Semiotics of Theatre and Drama, Methuen, Londres. <http://dx.doi.org/10.4324/9780203426074http://search.crossref.org/?q=ELAM\%2C+ KEIR+\%281980\%29\%3A+The+Semiotics+of+Theatre+and+Drama $\% 2 \mathrm{C}+$ Methuen $\% 2 \mathrm{C}+$ Londres.>

FERRERAs, Daniel (2003): «La poética del desorden: hacia la definición semio-crítica de un género fantástico", Actas de las Segundas jornadas sobre literatura fantástica, Ministerio de Educación, Cultura y Deporte, Madrid, pp. 11-23

Freud, Sigmund (1919): «Lo siniestro», en E.T.A. Hoffmann, El hombre de la arena, José J. de Olañeta Editor, Barcelona, 1979, pp. 9-35. 
García BARrientos, José Luis (2008): «Teatro posdramático y juegos (de manos) con la realidad», PasoDeGato. Revista mexicana de teatro, 32, pp. 33-34.

(2001): Cómo se comenta una obra de teatro (edición corregida y aumentada), Toma, Ediciones y Producciones Escénicas y Cinematográficas, A. C., México D. F.2012

(1980): «Identificación y distancia», en Teatro y ficción, Fundamentos, Madrid, 2004, pp. 101-110.

Нову, Hermione (2011): "American horror theatre: "A hand slams into my neck and wrenches me through the darkness"», The Observer, 4 de diciembre, disponible en <http://www.theguardian.com/travel/2011/dec/04/america-horror-theatre $>$ [Consulta: 17/10/14].

KING, Stephen (1987): Danse Macabre, Simon \& Schuster, Nueva York, 2010.

Lehmann, Hans-Thies (1999): Postdramatic Theatre, Routledge, Oxford, 2006. <http://dx.doi.org/10.4324/9780203088104 http://search.crossref.org/?q=LEHMANN\%2C+Hans-Thies+\%281999\%29\%3A+Postdramatic+Theatre \%2C+Routledge $\% 2 \mathrm{C}+\mathrm{Oxford} \% 2 \mathrm{C}+2006 \% 2 \mathrm{C}>$

LovecrAft, Howard Phillips (1927): El horror sobrenatural en la literatura, Leviatán, Buenos Aires, 1998.

NymAN, Andy (2014): «Theatre Can Outdo Cinema for Horror - So Where Are All the Scary Plays?», The Guardian, 14 de febrero, disponible en <http://www.theguardian.com/stage/2014/feb/14/ghost-stories-horror-in-theatre> [Consulta: $17 / 10 / 14]$.

Palacios, Jesús (2002): «Los escenarios del miedo. Un recorrido por los espacios del terror», en Vicente Domínguez (ed.), Los dominios del miedo, Biblioteca Nueva, Madrid, pp. 193-215.

PAvis, Patrice (2008): Contemporary Mise en Scène, Routledge, Oxford, 2013. (1996): Diccionario del teatro, Paidós, Barcelona, 1998.

Red Teatral (s. a.): «El teatro del terror», Red Teatral, no. 28, disponible en <http:// www.redteatral.net/noticias-el-teatro-del-terror-28> [Consulta: 17/10/14]).

RoAs, David (2011): Tras los límites de lo real. Una definición de lo fantástico, Páginas de Espuma, Madrid.

SÁnchez, José Antonio (2006): Prácticas de lo real en la escena contemporánea, Visor, Madrid.

SÁNCHEZ, Sergi (2002): «Pánico en la escena. Miedo real y miedo representado», en Vicente Domínguez (ed.), op. cit., pp. 303-318.

SAVATER, Fernando (2002): «Filmar el miedo», en Vicente Domínguez (ed.), op. cit., pp. 319-330.

Todorov, Tzvetan (1970): Introducción a la literatura fantástica, Premia, México D. F, 1981.

Wright, Angela (2007): Gothic Fiction, Palgrave Macmillan, Nueva York. 